Original Article

\title{
ANATOMICAL STUDY ON PRESENCE OF MULTIPLE ACCESSORY WHARTON'S DUCT AND ITS CLINICAL IMPORTANCE
}

\author{
Anita $^{*}$, Prabhjot Kaur Chhabra*, Baljeet Singh Khanduja**, Bali Sharma*, Sachindra Kumar Mittal ${ }^{\star}$ \\ ${ }^{*}$ Department of Anatomy, Jaipur National University Institute for Medical Sciences and Research Centre, \\ Jaipur, Rajasthan, India. \\ ${ }^{* *}$ Department of Ear Nose \& Throat, Fortis Escorts Hospital, Jaipur, Rajasthan,India.
}

\begin{abstract}
Introduction: Submandibular salivary glands are paired salivary glands that lie below the mandible on each side. The gland is drained by a single submandibular duct or Wharton's duct. It opens in the summit of the sublingual papilla. The duct lies between the lingual nerve and hypoglossal nerve on hyoglossus muscle. The aim of this study is to describe the multiple accessory submandibular duct or Wharton's duct.

Material \& Methods: A total of 28 submandibular regions were used during routine dissection classes of $1^{\text {st }}$ year MBBS students in year 2016-2018, to demonstrate the anatomical variations and presence of multiple accessory Wharton's duct. This study was conducted inJaipur National University Institute for Medical Sciences and Research Centre, Jaipur,Rajasthan, India.

Results: In our study, total incidence of variation was $14.2 \%$. Wharton's duct or submandibular duct was double in $7.1 \%$, three submandibular ducts were present in $3.5 \%$ and four submandibular ducts were present in $3.5 \%$ specimens.
\end{abstract}

Conclusion: Appreciation of these variations is very important in diagnostic and therapeutic techniques. Awareness of variations of the accessory ducts can help surgeons during oral surgical procedures.

Keywords: Submandibular gland, submandibular duct, variation, accessory, sialolithiasis.

\section{INTRODUCTION}

Submandibular salivary glands are paired salivary gland that lie below the mandible on each side. They consist of a larger superficial and smaller deep part,continuous with each other around the posterior border of mylohyoid muscle. It is a seromucous but predominantly serous gland $[1,2]$.

The gland is drained by a single submandibular duct or Wharton's duct [2-4] and is about $5 \mathrm{~cm}$ long.It begins from numerous tributaries in the superficial part of the gland and emerges from the medial surface of this part of the gland at the posterior border of the mylohyoid. It bends sharply at the posterior margin of mylohyoid to form the genu of submandibular ductthen it runs forwards between mylohyoid and hyoglossus to open in the anterior part of floor of the mouth (linguogingival) on the summit of the sublingual papilla on each side of the frenulum of the tongue [1]. The duct lies betweenthe lingual nerve and hypoglossal nerve on hyoglossus muscle but it presents an intimate relation with the lingual nerve.At first the lingual nerve lies above the duct then crosses its lateral side and finally ascends medially winding round the lower border of the duct $[1,2]$.

Embryologically, the submandibular gland develops in fifth to sixth week of intrauterine life. Primordial cords arise in the anterior alveololingual groove and grow in the floor of the mouth. Primordial 
cells proliferate into the underlying mesenchymal tissue, the duct branches repeatedly during this evagination process. Condensation of the deep cervical fascia produces the external capsule [5].

Most of the accessory submandibular ducts are detected incidentally during sialography [6-8]. Sialography is a diagnostic procedure of choice for the detection of structural variations of submandibular gland and duct including trauma, inflammatory disorders and calculi $[9,10]$.

In this study, these variations were found by dissection of the cadavers. The cadavers are important report sources that aim to demonstrate the structural differences inspecimensof the human body.

Awareness of variations of salivary gland duct can aid in the accurate diagnosis and treatment, it helps surgeons to avoid duct laceration during oral surgery and further complications.

The aim of this study was to describe the anatomical variation of multiple accessory submandibular duct and its morphological features.

\section{MATERIALS AND METHODS}

The present study was conducted in the Anatomy department of Jaipur National University Institute for Medical Sciences and Research Centre, Jaipur, Rajasthan, India, to demonstrate the anatomical variations and presence of multiple accessory Wharton'sduct.

A total of 28 submandibular regions ofadult embalmed cadavers were dissected and studied during routine dissection classes for $1^{\text {st }}$ MBBS students in year 2016-2018. The cadavers had no signs of trauma or operation in submandibular region. First of all, marginal mandibular incision was made from mastoid process to the chin and midline skin incision in neck from chin to the sternum was given to reflect the skin inferolaterally [11].

Wharton's duct and multiple accessory Wharton'sducts were explored and examined for its emergence, course and its opening in oral cavity. The details of the variation were recorded and photographed.

\section{OBSERVATIONS AND RESULTS}

Incidence of multiple accessory submandibular ducts was found in 4 submandibular regions i.e. total incidence was $14.2 \%$.Two submandibular ducts were found in 2 cases $(7.1 \%)$. Three submandibular ducts were found in 1 case (3.5\%) and four submandibular ducts were also found in 1 case $(3.5 \%)$. Variations were in the disposition and location of the multiple accessory submandibular ducts. Two submandibular ducts i.e. duplication of ducts was noted in two submandibular glands one on right side and one left side. Emergence, course and opening of accessory ducts were carefully noted. These ducts were almost parallel to each other, passing between the hyoglossus and mylohyoid muscles. In this, one duct was smaller and superior in position and second duct was larger and inferior in position. The superior duct was crossed laterally by the lingual nerve. Both ducts emerged independently from the deep part of the gland and opened separately into the floor of the mouth. The main duct opened at the sublingual papilla. The accessory duct opened adjacent to the main duct (Fig. 1). One submandibular salivary gland of left side had three submandibular ducts. These three ducts were arising independently from the deep part of submandibular gland. They were almost parallel to each other, passing between hyoglossus and mylohyoid muscles. The main duct $\left(2^{\text {nd }}\right)$ was middle in position and accessory ducts were located superior and inferior to it. The $3^{\text {rd }}$ duct was narrowest, longest and inferior most in position. The lingual nerve was crossing lateral side of superior duct $\left(1^{\text {st }}\right)$ and middle duct $\left(2^{\text {nd }}\right)$ then passed between middle and inferior ducts. The upper two ducts opened into sublingual papilla and the inferior duct opened adjacent to the main sublingual papilla (Fig. 2). One submandibular salivary gland of left side had four submandibular ducts. These ducts were emerging separately from deep part of the gland. They were different in length and thickness. The $1^{\text {st }}, 2^{\text {nd }}$ and $3^{\text {rd }}$ accessory ducts were thinner and smaller. The location of $4^{\text {th }}$ duct or main duct was inferior most and it was longest and thickest. The lingual nerve was crossing lateral side of $1^{\text {st }}, 2^{\text {nd }}$ and $3^{\text {rd }}$ ducts then it passed between $3^{\text {rd }}$ and $4^{\text {th }}$ duct. The main duct was opening in the sublingual papilla and rest three accessory ducts opened independently into lingulogingival groove up to second molar tooth (Fig. 3). 


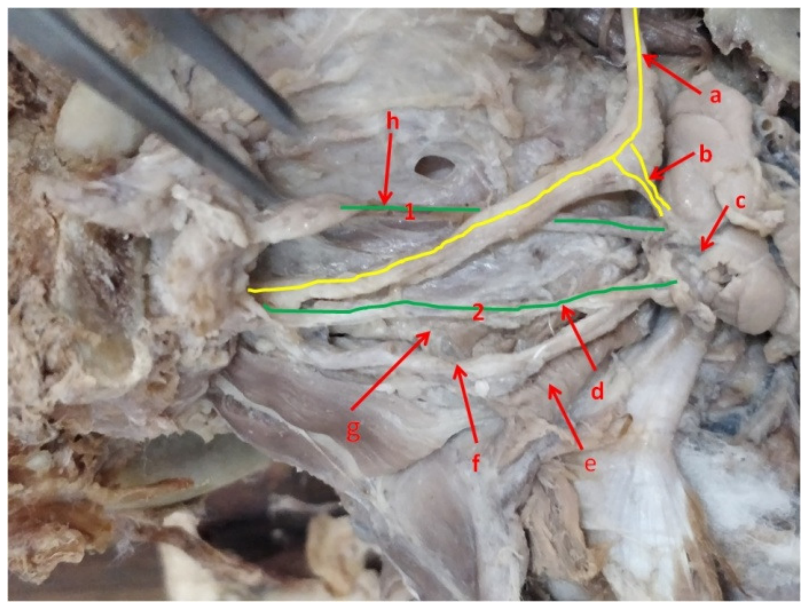

Fig. 1: Photograph showing submandibular region of left side, having two submandibular ducts $(1 \& 2)$. (a) Lingual nerve (b) Submandibular ganglion (c) Deep part of the submandibular gland (d) Accessory submandibular duct $\left(2^{\text {nd }}\right)$ from deep part of gland (e) reflected part of Mylohyoid muscle (f) Hypoglossal nerve (g) Hyoglossus muscle $(h)$ Main submandibular duct (Wharton's duct) $\left(1^{\text {st }}\right)$ from deep part of the gland

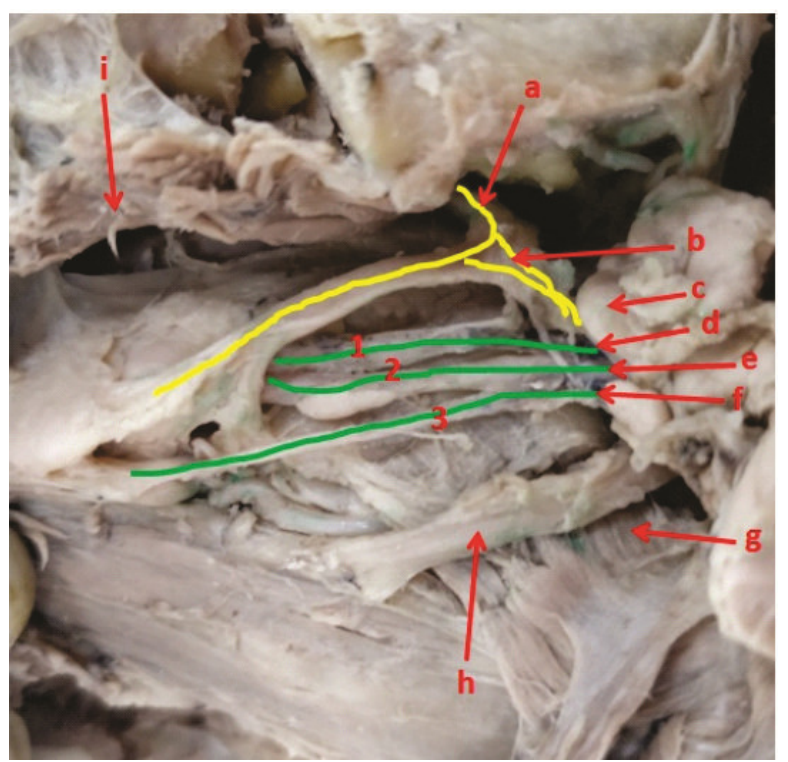

Fig. 2: Photograph showing submandibular region of left side, having three submandibular ducts $(1,2 \& 3)$. (a) Lingual nerve (b) Submandibular ganglion (c) Deep part of the submandibular gland (d) $1^{\text {st }}$ is accessory submandibular duct (e) $2^{\text {nd }}$ is Main submandibular duct (Wharton's duct) (f) $3^{\text {rd }}$ is accessory submandibular duct (g) Hyoglossus muscle (h) Hypoglossal nerve (i) Reflected part of Mylohyoid muscle

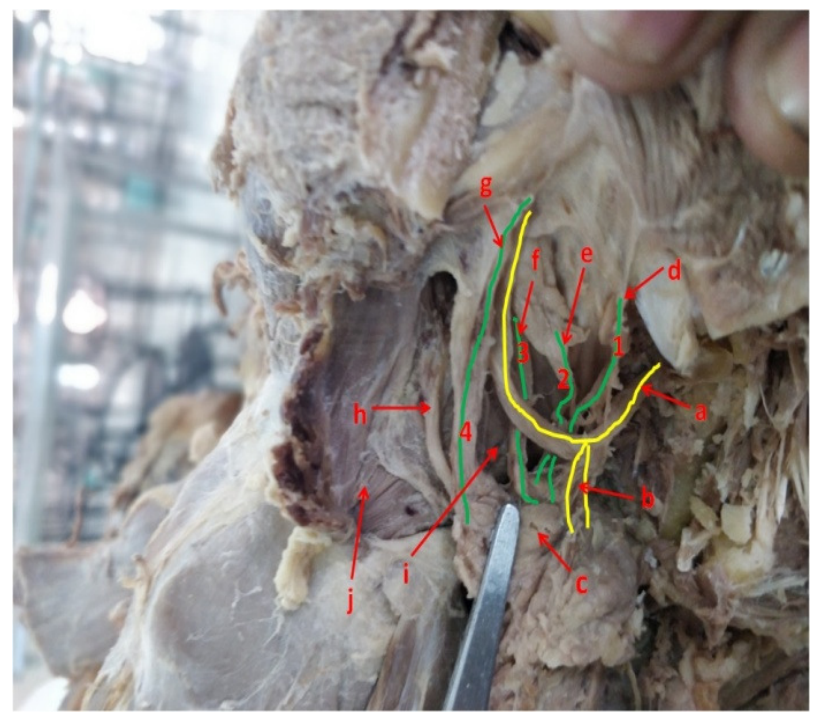

Fig. 3: Photograph showing submandibular region of left side, having four submandibular ducts (1-4) (a) Lingual nerve (b) Submandibular ganglion (c) Deep part of the submandibular gland (d) $1^{\text {st }}$ was accessory submandibular duct (e) $2^{\text {nd }}$ was accessory submandibular duct (f) $3^{\text {rd }}$ was accessory submandibular duct $(\mathrm{g}) 4^{\text {th }}$ was Main submandibular duct ( Wharton's duct) (h) Hypoglossal nerve (i)Hyoglossus muscle (j) reflected part of Mylohyoid muscle

\section{DISCUSSION}

The most frequent disorders that require surgical excision of the submandibular gland and submandibular duct are chronic inflammation of the gland with or without sialolithiasis and it requires anatomical knowledgeand careful protection of the surrounding structures.

Billakanti (2016) presented a case of accessorysubmandibular duct in which both the main and accessory ducts opened separately into the floor of the mouth on the right side of the frenulum of the tongue [12]. Kuroyanagi et al. (2007) observed duplication of the submandibular duct via sialographic examination [6]. In our study, two parallel submandibular ducts were found in two cases; both ducts emerged independently from the deep part of submandibular gland and opened separately into the floor of the mouth. In one case, the upper duct was crossed inferomedially by the lingual nerve and in second case the lower duct was crossed inferomedially by the lingual nerve.

Gaur et al. (1994) described a right submandibular gland with three separate ducts which opened independently into the oral cavity.The authors 
considered that the duct branches in an arboreal fashion, increasing in number and decreasing in caliber. If multiple primordia develop it would lead to the formation of multiple ducts, the glandular tissue of these primordia if closely placed and compactly covered by connective tissue, should form a single submandibular gland having multiple ducts,each were opening separately in the mouth [13]. In our study, we found one submandibular gland with three separate ducts. These three ducts were arising independently from the deep part of the gland. The three ducts were almost parallel to each other. The main duct was larger and middle in position and accessory ducts were slightly narrower. The upper two ducts opened into sublingual papilla and the inferior duct opened adjacent to the main sublingual papilla.

Rare variations of duct arrangement may occur. Rose (1932) described a case in which Wharton's duct bifurcate, with one end opening into the sublingual papilla and a second into the mouth opposite the second molar [14].

Arquez (2017) observed the excretory duct of the left submandibular gland that had an external location that ascends and crosses vertically off the body of mandible. At its termination it was divided into four ducts that had separate openings into the oral cavity, upon a small papilla independently, opposite to the first and second lower molar crown [15]. In our study, we found one submandibular gland with four separate ducts. These ducts were emerging separately from deep part of the gland. They were different in length and thickness. The location of main duct was inferior most and it was longest and thickest. The main duct was opening as usual in the sublingual papilla and rest three accessory ducts opened independently into lingulogingival groove up to second lower molar tooth.

Awareness of the possibility of multiple ducts or variations in the position of ducts is important for surgeons and radiologists. Radiolucent stones or any other pathology present in the accessory duct may be overlooked if sialography is not performed into each of these ducts. Majority of salivary calculi are radioopaque and are seen on plain X-ray film, about $20 \%$ of these are radiolucent [13]. Silography is regarded as diagnostic procedure of choice for the detection of various conditions of the salivary glands including trauma, inflammatory disorders and calculi [12].

The literature revealed previous reports of anatomical variations of the submandibular duct $[6,16$ 18]. The presence of double duct is important for a technique in which transfer of double duct (microvascular autologus mandibular gland transfer) is done for treating bilateral dry eyes [19].

This study may be useful for the sialography, sialoendoscopy and submandibular gland transfer. The good knowledge of anatomy is important for surgeons to reduce the injury of nerve in this area.

\section{CONCLUSION}

The presence of anatomical variations and multiple accessory Wharton's ducts were studied. We found duplication of submandibular duct in two cases, three submandibular ducts in one case and four submandibular ducts in one case. Appreciation of these variations is very important in diagnostic and therapeutic techniques. Awareness of variations of the excretory ducts can help surgeons during oral surgical procedures.

\section{REFERENCES}

1. Standring S. Gray's Anatomy- The Anatomical Basis of clinical practice. Oral cavity. $41^{\text {st }}$ ed. Spain, Elsevier Limited. 2016, pp. 527-531.

2. Datta AK. Essential of Human Anatomy- Head \& Neck. Submandibular and Parotid Region. $5^{\text {th }}$ ed. Kolkata, Current Books International. 2009, pp. 140-142.

3. Norman S. Williams. Bailey \& Love's- Short practice of surgery. Disorder of the salivary glands. $26^{\text {th }}$ ed. London, New York, CRC Press Taylor \& Francis Group. 2013, p. 726.

4. Josef E. Fischer. Fischer's Mastery of Surgery. Surgery of the Submandibular and sublingual salivary glands. Vol. $1,6^{\text {th }}$ ed. Gurgaon, Wolters Kluwer India Pvt. Ltd. 2012, pp. 298-300.

5. Patten BM. Human Embryology. $2^{\text {nd }}$ ed. New York, McGraw Hill. 1953.

6. Kuroyangi N, Kinoshita H, Machida J, Suzuki S, Yamada Y. Accessory duct in the submanibular gland. J Oral Maxillofac Surg Med Pathol. 2007; 19:110-12.

7. Codjambopoulo P, Ender-Griepekoven I, Broy H. Bilateral duplication of the submandibular gland and the submandibular duct. Rofo. 1992; 157:185-6.

8. Gadodia A, Seith A, Neyaz Z, Sharma R, Thakkar A. Magnetic resonance identification of an accessory submandibular duct and gland: An unusual variant. J Laryngol Otol. 2007; $121: \mathrm{e} 18$.

9. Gates GA, Johns ME. Diagnostic radiology. In: Paparella MM, Shumrick DA, editors. Otolaryngology. $2^{\text {nd }}$ ed. Philadelphia, Pennsylvania, USA: Saunders.1980, pp.1067-86.

10. Rice DH. Diagnostic imaging. In: Cummings CW, Fredrickson JM, Harker LA, Krause CJ, Schuller DE, editors. Otolaryngology. Head and Neck. $1^{\text {st }}$ ed. St Louis, Missouri, USA: Mosby. 1986, pp. 987-98. 
11. Rachel K. Cunningham's Manual of Practical Anatomy. Head, Neck and Brain. Anterior triangle of the neck. Vol. 3, $16^{\text {th }}$ ed. United Kingdom, Oxford University Press. 2018, pp. 51-56.

12. Billakanti PB. Accessory duct of submandibular duct of the submandibular gland. Sultan Quaboos Univ Med J. 2016; 17(1):e119-e120.

13. Gaur U, Chaudhry R, Anand C, Chaudhry S. Submandibular gland with multiple ducts. Surg Radiol Anat. 1994; 16:439-40.

14. Rose BH. Bifurcation of the submaxillary duct .Am J Surg.1932; 17:257-8.

15. Arquez HF. Anatomical variation of the submandibular gland duct. A unreported Anomaly. International Archives of Medicine. 2017; 10 (268).
16. Mori S, Wada T, Harada Y, Toyoshima S. Accessory duct in the submandibular gland. Oral Surg Oral Med Oral Pathol. 1986; 62:607-8.

17. Pownell PH, Brown OE, Pransky SM, Manning SC. Congenital abnormalities of the submandibular duct. Int $\mathrm{J}$ Pediatr Otorrhonolaryngol. 1992; 24:161-9.

18. Myerson M, Crelin ES, Smith HW. Bilateral duplication of the submadibular duct. Arch Otolaryngol. 1966; 83:488-90.

19. Horsburgh A, Massoud TF. The salivary duct of Wharton and Stenson: Analysis of normal variant sialographic morphometry and a historical review. Annals of Anatomy. 2013;195:238-242. 